\title{
Alarm raised over elephant ivory trade
}

Sir - We wish to express our concern over the resumption of a limited international trade in elephant ivory. The Convention on International Trade in Endangered Species (CITES) has allowed Namibia, Zimbabwe and Botswana to sell 59.8 tons of stockpiled ivory to Japan. The sales began in April, ending a ten-year ban. They are termed 'experimental', suggesting that, if deemed a success, further sales will be proposed.

When these sales were initially approved in June 1997, an important condition was attached - that a system should be developed to measure the impact of trade on elephant populations. The recent authorization reflects the satisfaction of CITES with a draft of a trade and elephant monitoring system called MIKE

(Monitoring Illegal Killing of Elephants). We feel that the approval of MIKE was inadvisable. This programme may be able to measure large-scale changes in populations, but it cannot gather the details needed to link subtle changes to causes.
Each of us has attempted to count elephants by various methods, and can attest that a reliable, sensitive census is difficult in the best of circumstances. We believe it would be nearly impossible to devise a method that was sensitive to minor changes in populations in varied environments and capable of relating these changes to underlying causes. At best, this would require measurements not included in MIKE's design. Without a good monitoring programme, the impact of the ivory trade will remain unknown.

We are also uncomfortable with the lack of a requirement for a monitoring system to be up and running before the current ivory trades were made. These omissions, and the notion that these sales are 'experimental', spell a dangerous situation for elephants.

CITES meets next in April 2000 in Nairobi. If further sales are proposed, these points must be made:

1) The lack of a satisfactory draft for a system to monitor the global elephant population and ivory trade means that there will not be enough information available in 2000 to justify further sales. 2) Any population-monitoring system must be scientifically credible, evidenced by peer review, which MIKE largely lacked when it was accepted by CITES.

3) Without a way of assessing the relationship between trade in ivory and the health of elephant populations, further sales must not be authorized.

This letter does not necessarily reflect the opinions of the writers' supporting institutions.

Katy Payne ${ }^{\star}$, Iain Douglas-Hamilton $\dagger$, Cynthia Moss $\ddagger$, Joyce Poole $\$$

* Bioacoustics Research, Cornell Laboratory,

Sapsucker Woods Road, Ithaca, New York 14850, USA $\dagger$ Save the Elephants, 7 New Square, Lincoln's Inn, London WC2A 3RA, UK

¥Amboseli Research, African Wildlife Foundation, 1400 Sixteenth Street, Washington, DC 20036, USA $\$$ Care for the Wild International, 1 Ashfolds,

Horsham Road, Rusper, West Sussex RH12 4QX, UK

\section{Guidelines point the}

\section{way on genetics ethics}

Sir - You reported that the World Health Organization (WHO) has published draft guidelines on bioethics (Nature 398, 175 \& $179 ; 1999)$. I would like to draw attention to an earlier effort completed by WHO in spring 1998 - "Proposed International Guidelines on Ethical Issues in Medical Genetics and Genetic Services". As corapporteur of these guidelines, I consider them some of the most comprehensive on ethical issues in clinical genetics, while they also address several research issues. The more recent general guidelines on bioethics reiterate some of their provisions.

WHO began its efforts on ethics and genetics in 1995, and a final document was drafted by 16 WHO experts in 1997 . The experts were divided on the issue of human cloning and refrained from making hasty conclusions, preferring to issue a compromise "statement of fact" that cloning "has been rejected by many international bodies" and "is not in accord with currently accepted international standards". Most of those present at the meeting considered cloning to be peripheral to the practice of medical genetics and of minor importance when compared to critical issues of access to services, fairness and education.

Since the proposed guidelines pertained mainly to services, rather than to research ethics, embryo research and germline gene therapy were not discussed. In general, the group opposed rushing to legislate for these ethical issues.

The proposed genetics guidelines were presented at the World Health Assembly in May 1998 and will be presented again in 1999. I would recommend readers to peruse them, and to comment or suggest revisions (http://www.who.int/ncd/hgn/

hgnethic.htm).

Dorothy C. Wertz

The Shriver Center for Mental Retardation, Inc., 200

Trapelo Road, Waltham, Massachusetts 02452, USA

\section{Genentech stands by}

\section{original data}

Sir - A trial is under way in San Francisco, California, involving a patent dispute between Genentech, Inc. and the University of California at San Francisco (see page 289 of this issue and ref. 1). During this trial, Peter Seeburg of the Max Planck Institute for Medical Research in Heidelberg, Germany, testified that data presented in a 1979 paper published in Nature ${ }^{2}$, of which he was a co-author, were false and that he knew they were false when the paper was submitted for publication.

As the other co-authors of that paper, we, together with Genentech, categorically deny this accusation that the data submitted in the Nature paper were false. We also emphatically disagree with Seeburg's statements, made under oath, that it is permissible to make up data on the basis of "similar work" because "it's all the same game", and that publishing a description of a non-existent plasmid is merely a "technical inaccuracy". We believe that to do as Seeburg suggests is both intellectually dishonest and antithetical to the principles on which scientific enquiry rests.

The trial is about patent infringement. The verdict, and the appeals that will doubtless follow, will be about that issue, not about the accuracy of the scientific conclusions of the paper. Nevertheless, we feel that these accusations have falsely impugned our reputation and cast doubts on our scientific integrity.

Genentech retains the notebooks upon which our 1979 Nature paper was based. They can be seen on the web at http://www.gene.com/notebooks/. In our view, these notebooks provide documentation that this work was indeed performed as described in the paper. We have invited the editors of Nature to examine these materials, and to speak to the co-authors, to satisfy themselves as to the accuracy of the paper. We would welcome such an opportunity to resolve these issues. Dennis J. Henner ${ }^{\star}$, David V. Goeddel $\dagger$, Herbert Heynekerł, Keiichi Itakura\$, Daniel Yansura*, Michael Ross 5 , Giuseppe Miozzari\#

${ }^{*}$ Genentech, Inc., 1 DNA Way, South San Francisco, California 94080, USA

$\dagger$ Tularik, Inc., Two Corporate Drive, South San 
Francisco, California 94080, USA

‡Eos Biotechnology, Inc., 225A Gateway Boulevard,

South San Francisco, California 94080, USA

\$Division of Immunology, Beckmann Research

Institute of the City of Hope, 1500 East Duarte Road,

Duarte, California 91010, USA

G MetaXen, 280 East Grand Avenue, South San

Francisco, California 94080, USA

\#HESKA, Gruengenstrasse 19, CH-4416 Bubendorf,

Switzerland

1. Marshall, E. Science 284, 883-886 (1999).

2. Goeddel, D. V. et al. Nature 281, 544-548 (1979).

\section{Statement from}

\section{Peter Seeburg}

Sir - I, as an inventor of a patent held by the University of California on cloned human growth hormone complementary DNA, was a witness in a trial involving a patent dispute between the university and Genentech (see page 289 of this issue and ref. 1).

My testimony concerned events that occurred 20 years ago, my work at the University of California, San Francisco (UCSF) and early work at Genentech, which collectively resulted in the expression of human growth hormone (hGH) in bacteria. This pioneering work with my colleagues at Genentech was the culmination of three years of previous efforts at UCSF by which I and my colleague John Shine had succeeded in cloning the main part of the coding sequence for human growth hormone. It had been a difficult personal time as this project had often involved working nights, owing to efforts by my lab head to stop my research on growth hormone, as documented in the 1987 book Invisible Frontiers: The Race to Synthesize a Human Gene by Stephen S. Hall (Tempus Books of Microsoft Press).

As I testified during the trial, the Nature paper $^{2}$ reporting the landmark study by Genentech regrettably contains a technical inaccuracy. This inaccuracy concerns a plasmid, pHGH31, which represents one of the intermediate steps in the construction of the expression vector for hGH. In this plasmid, the coding region for amino acids 24-191 plus 3' noncoding sequence, all contained on a 551-base-pair HaeIII complementary DNA fragment, is inserted by 'GC tailing' into the PstI site of pBR322. Not this plasmid, but an equivalent one carrying the same 551-base-pair HaeIII fragment inserted by linkers in the HindIII site of pBR322 and previously constructed by me and Shine at UCSF, was used as source of the natural coding region for amino acids 24-191 in the construction of the final hGH expression vector.

The existence of $\mathrm{pHGH} 31$ is questioned by the fact, acknowledged by Genentech, that there never was a sequence record showing hGH DNA sequence attached to a $\mathrm{G}$ or a $\mathrm{C}$ tail, even though such a record should have existed, according to the Nature paper. Several attempts at Genentech by a colleague and me to obtain pHGH31 were unsuccessful, primarily due to the poor quality of the RNA starting material available to us at the time. With increasing pressure to complete the expression work, my colleague and I agreed to use the University of California's cDNA clone for part of the work.

To be absolutely clear, I, like my coauthors, view it as mandatory that publications are correct in all aspects, including all technical and methodological details. Hence, I deeply regret that, contrary to my own principles and the principles of scientific endeavour, the Nature paper contains a technical inaccuracy.

As I emphasized during the trial, all scientific results and conclusions of the Nature paper are unambiguous and correct. The expression vector is exactly as described and the bacteria make the correct hormone at the levels described in the publication. The study reported in the paper forms the basis for the first human growth hormone preparation free of neurodegenerative agents ${ }^{3}$, and the first recombinant therapeutic to be marketed by Genentech, from which 100,000 children benefit worldwide.

Peter H. Seeburg

Department of Molecular Neuroscience,

Max-Planck Institute for Medical Research,

Jahnstrasse 29, 69120 Heidelberg, Germany

1. Marshall, E. Science 284, 883-886 (1999).

2. Goeddel, D. V. et al. Nature 281, 544-548 (1979).

3. Seeburg, P. H. "Human growth hormone: from clone to clinic" Cold Spring Harbor Symposia on Quantitative Biology 51, 669-679 (1986)

\section{Innocents suffer as}

\section{rogue regime rapped}

Sir - Christian Seelos's Commentary, "Lessons from Iraq on bioweapons", discussed only active warfare, where the weapons themselves contain infectious materials or biological toxins (Nature 398, $187-188 ; 1999)$. He failed to mention an equally nefarious kind of biological warfare, of the passive variety.

The bombing of Iraq during the Gulf War targeted infrastructure, with drastic effects on public health. One of the many results was a lack of water free of infectious particles, which led to a resurgence of bacterial infections, especially infantile diarrhoea, cholera and many other infectious diseases. The mortality rate for infants soared, with excess mortality of close to a million children, exacerbated no doubt by the severe malnutrition that the United Nations embargo has imposed.

One factor that exacerbated this problem was the lack of chlorine, which the UN Special Commission (UNSCOM) has decreed to be, in Seelos's sanitized phrase, "dual use". Eventually another UN agency, the children's fund UNICEF, campaigned to allow chlorine back, but the amount recently allowed is probably enough for only two or three cities. This kind of biological warfare is similar to poisoning wells or rivers upstream of besieged cities, which has its own long and notorious history.

Yet these issues are not discussed, perhaps because the personal viewpoint of Seelos, or the official one of UNSCOM, is that only when you lob the carcass of an infected animal into a besieged city do you commit the horrible crime of biological warfare. Or else, they might simply state, in the words made famous 50 years ago, that they were only following orders.

How many more people have to die before we decide that the price of our policies towards the rogue regime of the day is unsupportable?

\section{Qais Al-Awqati}

Department of Medicine, Columbia University, 630 West 168th Street, New York 10032, USA

\section{Science powerhouse}

\section{ofCentral America}

Sir-Small is beautiful, but when you are small nobody sees you. Democratization of Latin America is our chance to progress as a region, as your supplement on Science in Latin America demonstrates (Nature 398 (Suppl. 1 April); 1999). The articles on recent developments in Mexico, Chile, Argentina, Brazil and Cuba are inspiring. But only the largest countries of the region were considered. There are also small countries that have scientists who are trying to make a difference.

Costa Rica has a population of 3.5 million and a research budget much smaller than the US\$108 million indicated in the figure on page A5 of the supplement. Yet it produces more scientific papers than much larger and richer countries. It has been an uphill challenge for us, however. The government is unsupportive of science, and we suffer all the maladies described in the supplement.

Even so, Costa Rica has managed to be the science powerhouse of Central

America, and we will continue our fight to advance science in this minuscule country. Jorge Cortés

CIMAR, Universidad de Costa Rica,

San Pedro, Costa Rica 